\title{
GLYCATION AND ADVANCED GLYCATION END-PRODUCTS IN LABORATORY EXPERIMENTS IN VIVO AND IN VITRO
}

\author{
Martin Beránek ${ }^{1}$, Daniela Novákováa ${ }^{2}$, Pavel Rozsíval ${ }^{2}$, Jaroslav Dršata ${ }^{3}$, Vladimír Paličkal
}

Charles University in Prague, Faculty of Medicine and University Hospital in Hradec Králové, Czech Republic: Institute for Clinical Biochemistry and Diagnostics ${ }^{1}$, Department of Ophthalmology2; Charles University in Prague, Faculty of Pharmacy in Hradec Králové, Czech Republic: Department of Biochemical Sciences ${ }^{3}$

Summary: The purpose of our study was to determine the amount of glycated proteins and advanced glycation end products (AGE) in cataractous lens homogenates of patients who underwent phacoemulsification, and to define a simple in vitro protein model of glycoxidation. Analysis of 30 cataractous lenses (15 diabetic and 15 non-diabetic) revealed a significant increase in both glycated lens proteins of diabetics compared with the controls $(0.15 \mathrm{vs} 0.08 \mathrm{nmol} / \mathrm{mg}$ protein, $\mathrm{P}<$ 0.01 ) and AGE-linked fluorescence at $440 \mathrm{~nm}$ ( $4.8 \mathrm{vs} 2.8 \mathrm{AU} / \mathrm{mg}$ protein, $\mathrm{P}<0.01)$. The presence of AGE fluorescence in lenses indicates the role of oxidative stress in cataractogenesis. Fifty-six days incubation of alanine and aspartate aminotransferases, used as model proteins, with $500 \mathrm{mM}$ D-fructose at 25 and $37^{\circ} \mathrm{C}$ led to a complete inhibition of ALT and AST activities. The fluorescence of both aminotransferases rose according to the chosen incubation temperature: $37^{\circ} \mathrm{C}>$ $25^{\circ} \mathrm{C}>4{ }^{\circ} \mathrm{C}$. ALT and AST incubated in a medium containing D-fructose are subject to nonenzymatic glycation followed by a consequent formation of AGE products. Our data: i) support the concept of glycation-glycoxidation pathway appearing in diabetic patients; ii) form a base for determination of the efficiency of various antioxidative compounds in vitro.

Key words: Glycoxidation; Glycation; Diabetes; Lens; AGE; Fluorescence; Protein; ALT; AST; Catalytic activity

\section{Introduction}

Chronic hyperglycemia is one of the most important initiating factors responsible for the development of long-term diabetic complications. During nonenzymatic glycation a stable ketoamine adduct is formed from glucose and free amino groups of proteins impairing their physiological functions in blood (e.g., fibrinogen, hemoglobin, plasminogen, antithrombin III, apolipoprotein A-I, apolipoprotein B-100, transferrin, erythrocyte spectrin, platelet calmodulin) $(5,6,8,13,16,19,21,23,34)$ and other tissues (cardiac myosin, peripheral nerve myelin, basic fibroblast growth factor, lens crystallins) $(9,14,18,35,37)$.

Moreover, glycation accelerates extensive oxidation reactions appearing in long-lived proteins that lead to tissue damage by cumulative formation of more permanent, irreversible cross-linked condensation products. Accumulation of advanced glycation end products (AGE) showing fluorescence at $440 \mathrm{~nm}$, such as $\mathrm{N}^{6}$-(carboxymethyl) lysine (CML), pyrraline, or pentosidine, have been implicated in development of retinopathy, nephropathy, neuropathy, connective tissue pathology, thromboembolic disorders, and atherosclerosis $(1,7,15,36,20)$.

Nonenzymatic glycation and oxidative stress play an important role in the multifactorial development of diabetic and senile cataracts $(12,29,30)$, a major cause of blindness worldwide. The only curative procedure involves replacement of the cataractous lens by a synthetic intraocular implant, as demonstrated in Fig. 1.

Previously published experiments studied cataractogenesis in human or animal lenses collected via intracapsular or extracapsular surgery. The current trend in ophthalmology is to remove cataract using phacoemulsification (ultrasound degradation, emulsification and aspiration of the lens nucleus fragments, cortex aspiration from the eye) and small incision surgery with implantation of the foldable intraocular lenses. The purpose of our study was to determine the amount of glycated proteins and AGE products in cataractous lens homogenates of patients who underwent phacoemulsification. On the basis of the fluorescence of lens AGE products we tried in the second part of the study to define a simple in vitro protein model allowing us to estimate the levels of glycation and glycoxidation products formed in various laboratory conditions.

\section{Material and Methods}

\section{Subjects}

Lens homogenates were obtained from thirty patients undergoing routine cataract surgery at the Department of 

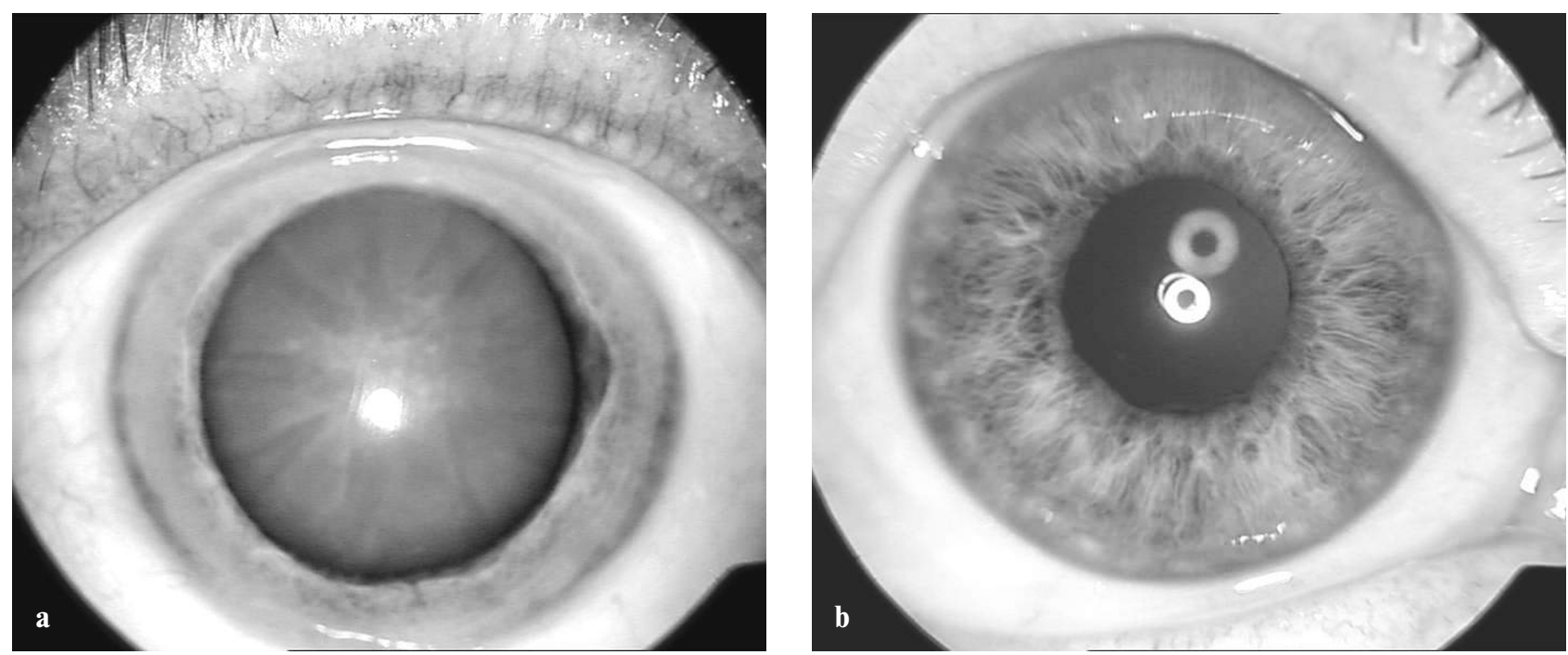

Fig. 1: Cataractous eyes before and after phacoemulsification. Slitlamp photo 1A shows the left eye of a woman, 73 years, suffering from mature cataract. Photo 1B demonstrates the clinical status two months after cataract surgery with the foldable intraocular lens.

Ophthalmology, University Hospital Hradec Králové with their written informed consent. The study was approved by the Ethical Committee of the Faculty of Medicine in Hradec Králové. The group consisted of 15 diabetics (5 men and 10 women, the median age 74 years, range 64-88) and 15 non-diabetic subjects ( 7 men and 8 women, the median age 72 years, range 53-89). Serum glucose, serum fructosamine (Hitachi 917, Roche Diagnostics, Mannheim, Germany), and concentrations of glycated hemoglobin (HbA1c) in erythrocytes (Variant II, Bio-Rad, Hercules, USA) were measured in all subjects immediately prior the experiment.

\section{Lens Analysis}

Cataractous lenses were extracted with the PHACOEmulsifier Aspirator (Alcon Laboratories, Fort Worth, USA) and saline lens homogenates were stored at $-20{ }^{\circ} \mathrm{C}$ until use. Thawed homogenates were disintegrated using a Tissue Tearor 985 (Biospec, London, UK). Ammonium sulphate $(14 \mathrm{~g})$ was added to $20 \mathrm{ml}$ of the homogenate to precipitate proteins for $20 \mathrm{~h}$ at $30{ }^{\circ} \mathrm{C}$. Centrifugation at $10,000 \mathrm{~g}$ for $25 \mathrm{~min}$ followed. The supernatant was removed and the dried sediment was reconstituted in $1.5 \mathrm{ml}$ of $10 \%$ trichloracetic acid and hydrolysed for $20 \mathrm{~h}$ at $5{ }^{\circ} \mathrm{C}$. After centrifugation (the same conditions as above), the protein pellet was received. The protein was weighed out into twisttop vials. The amount of early glycation products was determined by the 2-thiobarbituric acid (TBA) method according to the protocol of Blakytny et al. (3). The absorbance was recorded at $443 \mathrm{~nm}$. Glycation was determined from a standard graph obtained using D-fructose (Sigma, St. Louis, USA) standards. The values were expressed as nmol of fructose per mg protein.
The second part of the lens protein pellet was used for determination of AGE-linked fluorescence. The lens protein was digested with $20 \mu \mathrm{l}$ of proteinase $\mathrm{K}$ (Roche) at a concentration of $20 \mathrm{mg} / \mathrm{ml}$ in $1 \mathrm{ml}$ of $0.1 \mathrm{M}$ phosphate buffer, pH 7.4 at $70{ }^{\circ} \mathrm{C}$ for $90 \mathrm{~min}$. After $10 \mathrm{~min}$ centrifugation at $10,000 \mathrm{~g}$ the supernatant was used for fluorescence scanning in the Perkin-Elmer LS 50B spectrofluorometer. The excitation/emission wavelengths were set at 370 and $440 \mathrm{~nm}$, respectively. Excitation and emission slits were 10 $\mathrm{nm}$. The instrument was zeroed with $0.1 \mathrm{M}$ phosphate buffer containing $20 \mu \mathrm{l}$ of proteinase $\mathrm{K}$ only. The fluorescence was expressed in arbitrary optical units (AU) per milligram protein.

\section{In vitro experiment}

Purified alanine aminotransferase (ALT, EC 2.6.1.2) and aspartate aminotransferase (AST, EC 2.6.1.1) (Sigma) were incubated in the presence of $50 \mathrm{mM}$ or $500 \mathrm{mM}$ D-fructose for 56 days. D-fructose was chosen because of its higher glycation activity in comparison with D-glucose (31). Incubation temperatures were 4,25 or $37^{\circ} \mathrm{C}$. After incubation, changes in catalytic activities of both enzymes were measured using the Hitachi 917 analyzer. AGE-linked fluorescence was performed as above. The appropriate enzyme in $0.1 \mathrm{M}$ phosphate buffer ( $\mathrm{pH} 7.4$ ) incubated for 56 days as above was used as a control sample.

\section{Statistical analysis}

Because the data were not normally distributed, all measured variables in diabetic and non-diabetic subjects were compared using the Wilcoxon rank sum test. Results in tables are expressed as the medians and ranges. Differences are considered significant at the $5 \%$ level. 
Tab. 1: Biochemical variables in subjects underwent phacoemulsification of cataractous lenses. The values are expressed as the medians and ranges.

\begin{tabular}{|l|c|c|c|c|c|}
\hline & $\begin{array}{c}\text { Serum glucose } \\
(\mathrm{mmol} / \mathrm{l})\end{array}$ & $\begin{array}{c}\text { Serum } \\
\text { fructosamine } \\
(\text { umol/1) }\end{array}$ & $\begin{array}{c}\text { HbA1c } \\
(\%)\end{array}$ & $\begin{array}{c}\text { Glycated proteins } \\
\text { in lens } \\
(\mathrm{nmol} / \mathrm{mg})\end{array}$ & $\begin{array}{c}\text { AGE products } \\
\text { in lens } \\
(\mathrm{AU} / \mathrm{mg})\end{array}$ \\
\hline Diabetics $(\mathrm{n}=15)$ & $8.1(5.3-14.8)^{*}$ & $306(205-451)^{*}$ & $7.1(4.6-11.5)^{*}$ & $0.15(0.07-0.29)^{*}$ & $4.8(2.3-23.8)^{*}$ \\
\hline Non-diabetics $(\mathrm{n}=15)$ & $5.5(4.1-7.2)$ & $227(210-283)$ & $5.3(4.3-6.9)$ & $0.08(0.05-0.22)$ & $2.8(1.9-10.3)$ \\
\hline
\end{tabular}

* P < 0.01; Physiological ranges: glucose 3.6-6.2 mmol/1 (Hitachi 917, Roche); fructosamine 205-285 umol/1 (Hitachi 917, Roche); HbA1c 4.5-6.2 \% (Variant II, Bio-Rad, Hercules, USA)

Tab. 2: Experimental values determined in the aminotransferase samples after 56 days of incubation in vitro. Residual catalytic activities are related to the initial activities measured on day 0.

\begin{tabular}{|c|c|c|c|c|c|c|}
\hline Sample & \multirow{2}{*}{$\begin{array}{c}\text { Fructose } \\
(\mathrm{mmol} / \mathrm{l})\end{array}$} & \multicolumn{2}{|c|}{$\begin{array}{c}\text { Incubation } \\
\text { temperature }\end{array}$} & \multicolumn{2}{|c|}{$\begin{array}{c}\text { Residual catalytic activity } \\
(\%)\end{array}$} & \multicolumn{2}{c|}{$\begin{array}{c}\text { Fluorescence } \\
\text { (AU/mg protein) }\end{array}$} \\
& & ALT & AST & \multicolumn{2}{c|}{ ALT } & AST \\
\hline 1 & 0 & 4 & 59 & 108 & 7.5 & 5.6 \\
\hline 2 & 50 & 4 & 30 & 108 & 37.5 & 23.8 \\
\hline 3 & 500 & 4 & 25 & 67 & 114.3 & 85.8 \\
\hline 4 & 0 & 25 & 55 & 98 & 12.0 & 6.4 \\
\hline 5 & 50 & 25 & 0 & 35 & 42.9 & 28.8 \\
\hline 6 & 500 & 25 & 0 & 0 & 159.0 & 111.6 \\
\hline 7 & 0 & 37 & 0 & 98 & 8.4 & 6.2 \\
\hline 8 & 50 & 37 & 0 & 2 & 65.4 & 33.8 \\
\hline 9 & 500 & 37 & 0 & 0 & 280.5 & 144.4 \\
\hline
\end{tabular}

\section{Results}

The laboratory data describing glycemic control parameters of diabetic and non-diabetic subjects, both suffering from the cataractous lens, are summarized in Table 1. As expected, the diabetic group has statistically higher levels of serum glucose, serum fructosamine, and $\mathrm{HbA} 1 \mathrm{c}$ in erythrocytes than non-diabetics $(\mathrm{P}<0.01)$. Analysis of lenses revealed a significant increase in both glycated lens proteins of diabetics compared with the controls $(0.15 \mathrm{vs} 0.08 \mathrm{nmol} / \mathrm{mg}$ protein, $\mathrm{P}<0.01)$ and AGE-linked fluorescence at $440 \mathrm{~nm}$ (4.8 vs $2.8 \mathrm{AU} / \mathrm{mg}$ protein, $\mathrm{P}<0.01$ ). There were no associations between the AGE fluorescence and the concentration of serum glucose ( $r=0.23$, NS), fructosamine ( $r=0.25, \mathrm{NS})$, HbAlc ( $\mathrm{r}=0.15$, NS), or lens glycation $(\mathrm{r}=-0.42$, NS). Also, we did not find any relationship between the level of lens glycation and serum glucose ( $r=0.26$, NS), fructosamine $(r=0.29, \mathrm{NS})$, or HbAlc $(r=0.17, \mathrm{NS})$. Fig. 2 presents typical emission spectra of AGE products formed in the cataractous lenses.

Table 2 shows residual aminotransferase activities and AGE fluorescence in the samples after 56 days of incubation at different temperatures and concentrations of D-fructose. In both enzymes, the catalytic activity decreased in relation to the sugar concentration. $500 \mathrm{mM}$ fructose completely inhibited both aminotransferases at 25 and $37{ }^{\circ} \mathrm{C}$. The presence of $50 \mathrm{mM}$ fructose led to total inhibition of ALT at 25 and $37^{\circ} \mathrm{C}$. AST seems to be more stable in vitro at all three experimental temperatures. $50 \mathrm{mM}$ fructose only partially diminished its catalytic activity.

ALT and AST emission spectra showed that all three samples containing $500 \mathrm{mM}$ D-fructose provided a higher fluorescence maximum at $440 \mathrm{~nm}$ (at excitation wavelength of $370 \mathrm{~nm}$ ) than the $50 \mathrm{mM}$ D-fructose samples and the sugar-free controls (Table 2). The fluorescence of both aminotransferases rose according to the chosen incubation temperature: $37^{\circ} \mathrm{C}>25^{\circ} \mathrm{C}>4{ }^{\circ} \mathrm{C}$. Emission characteristics of ALT are shown in Fig. 3.

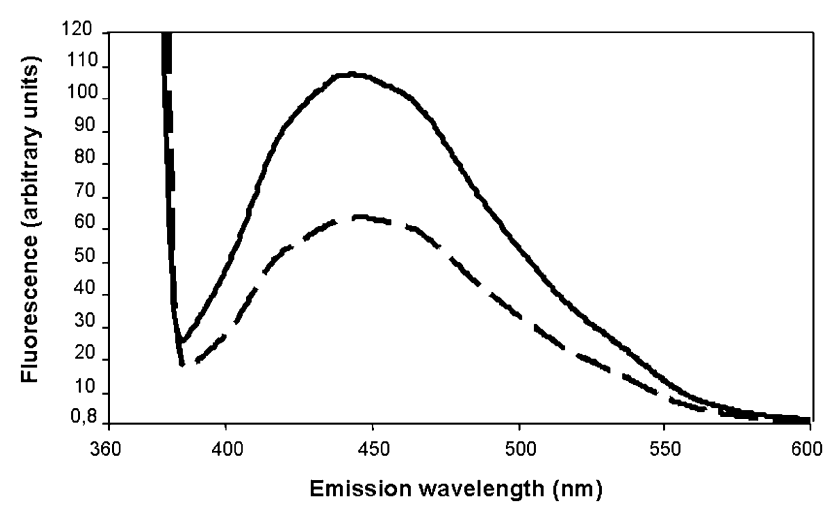

Fig. 2: Emission spectra of AGE products in diabetic (solid line) and non-diabetic (dashed line) cataractous lenses after phacoemulsification and protein extraction. Both the curves show the emission maximum at $440 \mathrm{~nm}$. 

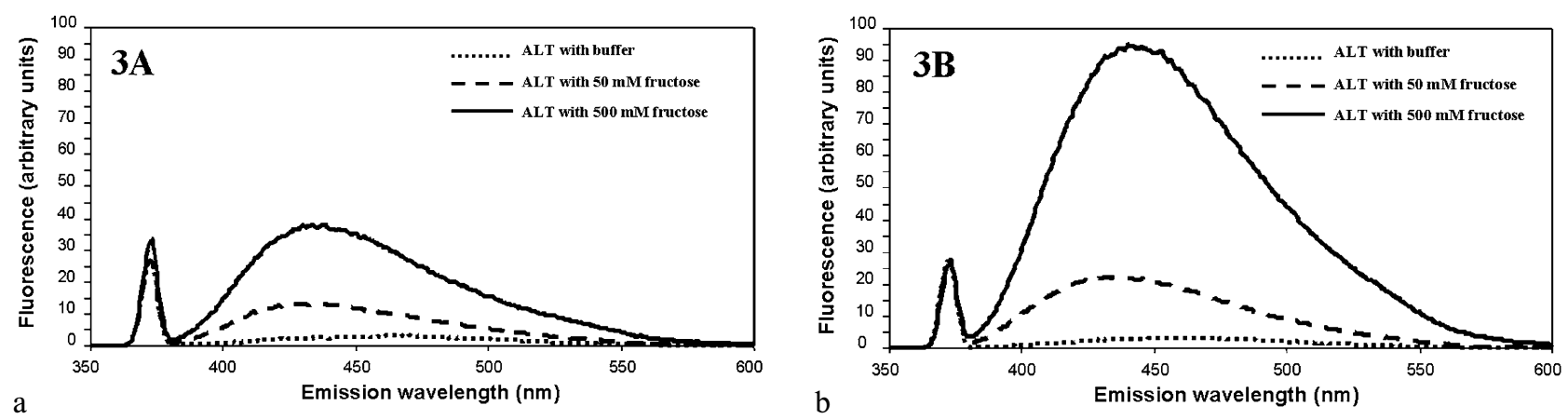

Fig. 3: Synchronous fluorescence spectra of ALT after 56-day incubation at the presence of $50 \mathrm{mM}$ or $500 \mathrm{mM}$ D-fructose at $4{ }^{\circ} \mathrm{C}(3 \mathrm{~A})$ or $37{ }^{\circ} \mathrm{C}(3 \mathrm{~B})$. Excitation wavelength: $370 \mathrm{~nm}$; emission wavelength: $440 \mathrm{~nm}$. The intensity of fluorescence depends on the chosen incubation temperature.

\section{Discussion}

Lens opacification is a complex phenomenon. The mechanisms underlying the apparent increased oxidative stress in diabetes are not entirely clear. Besides glycoxidation, other processes have been postulated to explain the role of diabetes in accelerating of cataract formation (polyol pathway, altered cell and glutathione redox status and ascorbic acid metabolism, perturbations in nitric oxide and prostaglandin metabolism, and lipid peroxidation) $(4,17)$.

AGE products accumulate in the lens over many years. In our study, the level of lens fluorescence in diabetics exposed to higher concentrations of glucose was almost twofold compared with the non-diabetic subjects $(\mathrm{P}<0.01)$. This fact indicates the role of oxidative stress in cataractogenesis. On the other hand, we did not find any significant associations between AGE-linked fluorescence or the amount of glycated proteins, and other examined biochemical parameters. We explain it by good diabetic control of the patients before the operation (see Table 1). Three of them were on insulin treatment, five were treated with oral agents, and seven were on diet.

As an in vitro model of glycoxidation we have chosen aminotransferases whose inhibition of catalytic activity reflects the degree of glycation $(2,11)$. Our results demonstrate that both ALT and AST incubated in a medium containing D-fructose, one of the most potent in vitro glycating agents, are subject to nonenzymatic glycation followed by a consequent formation of AGE products. AGE-linked fluorescence at $440 \mathrm{~nm}$ increased according to the used fructose concentration in the sample and to the incubation temperature. $500 \mathrm{mM}$ D-fructose induced a hundredfold elevation of fluorescence in relation to the sugar-free samples at $37^{\circ} \mathrm{C}$. Our data support the concept of glycation-glycoxidation pathway appearing in diabetics.

Since our measurement of AGE products in the samples was impeded by the lack of specificity, we were not able to establish how the process of D-fructose autooxidation contributes to the AGE fluorescence during the incubation. Using more advanced analytical techniques, such as enzyme- linked immunosorbent assay (10), radiotracer measurements (24), HPLC (22), or mass spectrometry $(25,32)$ should solve that question in the future.

A lot of substances preventing AGE formation in the body has been found and examined (aminoguanidine, ascorbic acid, tocopherol, lipoic acid, salicylic acid, indomethacin, carvedilil, captopril, superoxide dismutase mimetics, poly(ADP-ribose) polymerase inhibitors, or tenilsetam) (26-28,33). The fundamental application of our in vitro model should be to determine the efficiency of various compounds to reduce oxidation changes in proteins. We believe that in vitro models of browning reactions could be a hopeful strategy how to simply characterize new antioxidative drugs.

\section{Acknowledgement}

We wish to express our thanks to Mgr. Irena Žáková, Mgr. Markéta Steidlová, and Mgr. Filip Vyskočil, former students of the Faculty of Pharmacy, for their technical assistance.

This study was supported by the Charles University grant $128 / 2005$.

\section{References}

1. Beisswenger PJ, Moore LL, Brinck-Johnsen T, Curphey TJ. Increased collagenlinked pentosidine and advanced glycosylation end-products in early diabetic nephropathy. J Clin Invest 1993; 92: 212-7.

2. Beránek M, Dršata $J$, Palička V. Inhibitory effect of glycation on catalytic activity of alanine aminotransferase. Mol Cell Biochem 2001; 218: 35-9.

3. Blakytny R, Harding JJ. Prevention of cataract in diabetic rats by aspirin, paracetamol (acetaminophen) and ibuprofen. Exp Eye Res 1992; 54: 509-18.

4. Borchman D, Yappert MC, Rubini RG, Peterson CA. Distribution of phospholipid-malondialdehyde - adduct in the human lens. Curr Eye Res 1989; 8 : 939-46.

5. Brownelee M, Vlassara H, Cerami A. Inhibition of heparin-catalyzed human antithrombin III activity by nonenzymatic glycation. Diabetes 1984; 33: 532-5.

6. Bunn HF, Gabbay KH, Gallop PM. The glycosylation of hemoglobin: relevance to diabetes mellitus. Science 1978; 200: 21-7.

7. Cohen MP, Urdanivia E, Surma M, Wu VY. Increased glycosylation of glomerular basement membrane collagen in diabetes. Biochem Biophys Res Commun 1980; 95: 765-9.

8. Calvo C, Talussot C, Ponsin G, Berthezene F. Non enzymatic glycation of apolipoprotein A-I effects on its self-association and lipid binding properties. Biochem Biophys Res Commun 1988; 153: 1060-7.

9. Ditzel J. Oxygen transport impairment in diabetes. Diabetes 1976; 25: 832-8. 
10. Dolhofer-Bliesener R, Lechner B, Gerbitz KD. Possible significance of advanced glycation end products in serum in end-stage renal disease and in late complications of diabetes. Eur J Clin Chem Clin Biochem 1996; 34: 355-61.

11. Dršata J, Beránek M, Palička V. Inhibition of aspartate aminotransferase by gly cation in vitro under various conditions. J Enzyme Inhib Med Chem 2002; 17 31-6.

12. Ederer F, Hiller R, Taylor HR. Senile lens changes and diabetes in two population studies. Am J Ophthalmol 1981; 91: 381-95.

13. Geiger M, Binder BR. Nonenzymatic glucosylation as a contributing factor to defective fibrinolysis in diabetes mellitus. Haemostasis 1986; 16: 439-46.

14. Giardino I, Edelstein D, Brownlee M. Nonenzymatic glycosylation in vitro and in bovine endothelial cells alters basic fibroblast growth factor activity. J Clin Invest 1994; 94: 110-7.

15. Kohn RR, Schnider SL. Glucosylation of human collagen. Diabetes 1982; 31 $47-51$.

16. Krantz S, Lober M, Thiele M, Teuscher E. Properties of i vitro nonenzymatically glycated plasma fibrinogens. Exp Clin Endocrinol 1987; 90: 37-45.

17. Laaksonen DE, Atalay M, Niskanen L, Uusitupa M, Hanninen O, Sen CK Increased resting and exercise-induced oxidative stress in young IDDM men Diabetes Care 1996; 19: 569-74.

18. Liang JN, Chylack LT. Spectroscopic study on the effects of nonenzymatic glycation in human $\alpha$-crystallin. Invest Ophthalmol Vis Sci 1987; 28: 790-4.

19. McMillan DE, Brooks SM. Erythrocyte spectrin glucosylation in diabetes. Diabetes 1982; 31: 64-9.

20. Monnier VM, Vishwanath V, Frank KE, Elmets CA, Dauchot P, Kohn RR. Relation between complications of type I diabetes mellitus and collagen-linked fluorescence. N Engl J Med 1986; 314: 403-8.

21. Muruganandam A, Romsa GJ, Thibert RJ, Cheung RMC, Draisey TF, Mutus B Glycated calmodulin from platelets as an index of glycemic control. Clin Chem 1993; 39: 815-9.

22. Odetti P, Fogarty J, Sell DR, Monnier VM. Chromatographic quantification of plasma and erythrocyty pentosidine in diabetic and uremic subjects. Diabetes 1992; 41: 153-9.

23. Panteghini M, Cimino A, Pagani F, Girelli A. Nonenzymatic glycation of apolipoprotein B in patients with insulin- and noninsulin-dependent diabetes mellitus. Clin Biochem 1995; 28: 587-592.

24. Prabhakaram M, Ortweth BJ. Determination of glycation crosslinking by the sugar-dependent incorporation of (14C) lysine into protein. Anal Biochem 1994; 216: $305-12$

25. Prabhakaram M, Smith JB, Ortwerth BJ. Rapid assessment of early glycation products by mass spectrometry. Biochem Mol Biol Int 1996; 40: 315-25.

26. Ross AD, Sheng H, Warner DS, et al. Hemodynamic effects of metalloporphyrin catalytic antioxidants: structure-activity relationships and species specificity. Free Radic Biol Med, 33, 2002, 1657-69.
27. Shoda H, Miyata S, Liu BF, et al. Inhibitory effects of tenilsetam on the Maillard reaction. Endocrinology 1997; 138: 1886-92.

28. Soriano FG, Pacher P, Mabley J, Liaudet L, Szabo C. Rapid reversal of the diabetic endothelial dysfunction by pharmacological inhibition of poly(ADP-ribose) polymerase. Circ Res 2001; 89: 684-91.

29. Spector A. Oxidative stress induced cataract: mechanism of action. FASEB J 1995; 9: 1173.

30. Stevens VS, Rouzer CA, Monnier VM, Cerami A. Diabetic cataract formation: potential role of glycosylation of lens crystallins. Proc Natl Acad Sci USA 1978, 75: 2918-22.

31. Syrový I. Glycation of albumin: reaction with glucose, fructose, galactose, ribose or glyceraldehyde measured using four methods. J Biochem Biophys Methods 1994; 28: 115-21

32. Tang X, Sadeghi M, Olumee Z, Vertes A. Detection and quantification of $\beta-2$ microglobulin glycosylated end products in human serum by matrix-assisted laser desorption/ionization mass spectrometry. Anal Chem 1996; 68: 3740-5.

33. Thorpe SR, Baynes JW. Role of the Maillard reaction in diabetes mellitus and diseases of aging. Drugs et Aging 1996; 9: 69-77.

34. Van Campenhout A, Van Campenhout Ch, Lagrou AR, Manuel-Y-Keenoy B. Effects of in vitro glycation on $\mathrm{Fe} 3+$ binding and $\mathrm{Fe} 3+$ isoforms of transferrin. Clin Chem 2004; 50: 1640-9.

35. Vlassara H, Brownlee M, Cerami A. Recognition and uptake of human diabetic peripheral nerve myelin by macrophages. Diabetes 1985 ; 34 : 553-7.

36. Witztum JL, Steinberg D. Role of oxidized low density lipoproteins in atherosclerosis. J Clin Invest 1991; 88: 1785-92.

37. Yudkin JS, Cooper MB, Gould BJ, Oughton J. Glycosylation and cross-linkage of cardiac myosin in diabetic subjects: A post-mortem study. Diabetes Medicine 1988; 5 : 338-42.

Submitted May 2005.

Accepted March 2006

PharmDr. Martin Beránek, PhD,

Charles University in Prague,

Faculty of Medicine and University Hospital,

Institute for Clinical Biochemistry and Diagnostics,

Sokolská 581,

50005 Hradec Králové,

Czech Republic.

e-mail: beranek@lfhk.cuni.cz 